\title{
Beszámoló a II. Területfejlesztők Napjáról
}

\section{Report on the 2nd Congress of Spatial Developers}

\author{
KOVÁCS SÁNDOR ZSOLT, RÁCZ SZILÁRD, TIPOLD FERENC
}

\begin{abstract}
KOVÁCS Sándor Zsolt: tudományos segédmunkatárs, MTA Közgazdaság- és Regionális Tudományi Kutatóközpont, Regionális Kutatások Intézete, Pécs; skovacs@rkk.hu RÁCZ Szilárd: tudományos titkár, MTA Közgazdaság- és Regionális Tudományi Kutatóközpont, Regionális Kutatások Intézete, Pécs; szracz@rkk.hu

TIPOLD Ferenc: főosztályvezető, Nemzetgazdasági Minisztérium, Területfejlesztési Tervezési Főosztály, Budapest; ferenc.tipold@ngm.gov.hu
\end{abstract}

\begin{abstract}
Sándor Zsolt KOVÁCS: junior research fellow, Institute for Regional Studies, Research Centre for Economic and Regional Studies, Hungarian Academy of Sciences, Pécs; skovacs@rkk.hu Szilárd RÁCZ: scientific secretary, Institute for Regional Studies, Research Centre for Economic and Regional Studies, Hungarian Academy of Sciences, Pécs; szracz@rkk.hu

Ferenc TIPOLD: head of department, Department of Territorial Development Planning, Ministry for National Economy, Budapest; ferenc.tipold@ngm.gov.hu
\end{abstract}

A Magyar Regionális Tudományi Társaság (MRTT) második alkalommal rendezte meg a Területfejlesztők Napját, ezúttal a Nemzetgazdasági Minisztérium Tervezéskoordinációért Felelős Államtitkárságának támogatásával. A 2013. október 8-án, Budapesten, a Nemzetgazdasági Minisztérium Pénztártermében megtartott tanácskozás arra kereste a választ, hogy miképpen lehet a jövőben érvényesíteni az elfogadás előtt álló Országos Fejlesztési és Területfejlesztési Koncepció (OFTK $)^{1}$ célkitűzéseit, milyen tervezési megfontolásokra, operatív lépésekre van szükség a területi szempontok eredményesebb érvényesítése érdekében. A konferencia iránt komoly érdeklődés mutatkozott, mindössze négy munkanap után, kapacitáskorlát miatt befejeződött a regisztráció. A 140 résztvevő által képviselt szervezetek megoszlása (akadémiai szektor 27\%, kormányzat 24\%, nonprofit szervezetek 19\%, megyei önkormányzatok 17\%, tanácsadó cégek és egyéb szervezetek 13\%) jól tükrözte a szakma sokszínűségét. A területfejlesztési politika alakítói és annak gyakorlati megvalósítói élénk figyelemmel kísérték a bemutatott szakmai és tudományos eredményeket.

Rechnitzer János, az MRTT elnöke és Greinstetter Balázs gazdaságtervezésért felelős helyettes államtitkár köszöntőjét követően a délelőtti ülés a legfontosabb fejlesztési célok, eszközök és dokumentumok kapcsolatrendszerét, érvényesülését és dilemmáit vitatta meg. Salamin Géza, a Nemzetgazdasági Minisztérium Területfejlesztési Tervezési Főosztályának vezetője előadásával

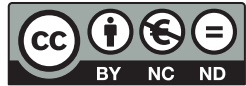


megalapozta a konferenciát, a 2007-2013 közötti európai uniós tervezési ciklus tapasztalataira építve bemutatta az új periódusban elvárt integrált tervezési szemlélet cél- és eszközrendszerét. Kitűnt, hogy a gazdasági (nemzeti kitettség, a foglalkoztatás alacsony szintje, gyenge $\mathrm{K}+\mathrm{F}$-intenzitás), társadalmi (elöregedés, népességcsökkenés, bizalomhiány, agyelszívás) és környezeti (rossz környezeti infrastruktúra, pazarlás, az energiahatékonyság hiánya) kihívások mind-mind összefüggésben vannak a területi egyenlőtlenségek további növekedésével. Éppen ezért a problémák megoldására integrált koncepció megalkotása szükséges, ezt a szemléletet az OFTK célrendszere meg is valósítja.

Péti Márton, a Nemzetgazdasági Tervezési Hivatal Stratégiai és Területi Tervező-értékelő Főosztályának vezetője a partnerségi megállapodásban megjelenő területi elemekről és a tervezés dilemmáiról beszélt. A dokumentum területi vonatkozásai nem elhanyagolhatók, megjelennek benne a területileg decentralizált fejlesztések, a területi nyomon követés és az értékelés. Emellett több kérdés megválaszolása is a megállapodás részét képezi, így uniós szintü dilemma a területi vagy a tematikus fejlesztések végrehajtásának kérdése, valamint a regionális és a vidékfejlesztés kapcsolatrendszere. Magyarországon is el kell dönteni a területiség megjelenítésének módját, a hatékonyság vizsgálatával választani szükséges a területi logikával átgondolt ágazati fejlesztések és a bottom-up típusú, valós decentralizáción alapuló fejlesztési megoldások közül.

Faragó László, az MTA KRTK Regionális Kutatások Intézetének tudományos főmunkatársa a hazai tervezés, a tervek összefüggéseire, a rendszer és a konzisztencia hiányosságaira hívta fel a hallgatóság figyelmét. Kritikus észrevételeiben kitért arra, hogy a 2010 óta életbe lépett számtalan terv és stratégia szakmai színvonala, társadalmi elfogadottsága eltérő, egyes tervek pusztán kommunikációs célokat szolgáltak, ami önmagában hordozza a koherencia hiányát. A rendszerré alakításhoz, az uniós tervezéshez való jobb kapcsolódáshoz olyan változtatások szükségesek, mint a különböző dokumentumok közötti hierarchia és feladatmegosztás, a jobb időbeli alkalmazkodás a programozási ciklusokhoz, a partneri kapcsolatokon alapuló stabilitás a végrehajtásban, és ami a legfontosabb, a konkrét, egyértelmű szabályozás (pl. tervtörvény). A tervek összehangolt rendszere szükséges az olyan, még meg nem oldott feladatok elvégzésére, mint a területi szintek közötti funkciómegosztás és a településhálózat kérdései.

A területi szinten alkalmazható integrált tervezés lehetőségeiről hangzott el Finta Istvánnak, az MTA KRTK Regionális Kutatások Intézete tudományos munkatársának előadása, melynek kiindulópontját a közösségi stratégiai keret adta. A dokumentum önmaga jeleníti meg az integrációt, hiszen már nem az egyes pénzügyi alapok elszigetelt müködése a lényeges a jogalkotó számára, hanem a közös célok elérését segítő valamennyi alap együttes közreműködésével (multifund) létrejött tervezés. E szemlélet két területi vonatkozású eszközt kínál fel a tervezésnek: az integrált beruházást (ITI) és a közösségvezérelt helyi fejlesztést (CLLD). Integrált fejlesztés megvalósítható bizonyos ágazatban, szakterületen, de adott területi egységben is, ez utóbbinál követelmény az érintett 
földrajzi tér viszonylagos homogenitása, hiszen nagyon eltérő sajátosságok, jellemzők esetén aligha lehetséges integrált program végrehajtása. A közösségi irányítású helyi fejlesztés az ITI-k megvalósításának egyik építőeleme lehet, így nélkülözhetetlen a közös programozás, a Terület- és Településfejlesztési Operatív Program mellett az ágazati programok területi kapcsolódási pontjainak kialakítása, meghatározása.

A konferencia délutáni ülését Szaló Péter, a Belügyminisztérium területrendezési, építésügyi és örökségvédelmi helyettes államtitkárának előadása nyitotta A rendezés és fejlesztés viszonya címmel. Alapkérdése a rendezés és a fejlesztés időbeliségének kapcsolata volt. Az értelmezések többsége szerint a tervezés rendszerében elöször a vízió, a fejlesztési akarat születik meg, melynek térbeli kereteit a rendezés határozza meg. Az elméleti keretek meghatározása után az előadó vázolta az Országos Területrendezési Terv (OTrT) sajátosságait, így annak nagy, jövőképszerű (15-20 év) időtávlatát, országos léptékét, keretrendszerjellegét, melynek előírásai a megyei, települési szintủ tervdokumentumokban érvényesülnek. Az általánosságok bemutatása mellett különböző konkrét (vízgazdálkodási, agrártérségi, infrastrukturális, energetikai hálózati és csomóponti) lehatárolásokat részletezett az előadás. Végül a jelenlevők megismerhették az OTrT elkészülésének folyamatát az álláspontok megfogalmazásától a Parlament elé kerülésig.

Fazekas Károly, az MTA Közgazdaság- és Regionális Tudományi Kutatóközpont főigazgatója a foglalkoztatás és a munkanélküliség területi kérdéseit vizsgálta. A gazdaság statisztikai mutatói (foglalkoztatás, GDP) alapján az a globális tendencia, miszerint a vállalkozások, országok, régiók és városok egyre jobban elkülönülnek anyagi viszonyaikban, egyre inkább jellemzi hazánkat is. E folyamatok jól kivehetők a GDP regionális megoszlásának növekvő különbségeiben, a foglalkoztatás és a munkanélküliség, a gyors növekedésű vállalkozások (gazellák) polarizációjában. A régiók fejlődését a versenyképesség javulása segíti elő, amely egyre komplexebb képességek elsajátítását igényli annak érdekében, hogy képesek legyenek magasabb termelékenységü tevékenységek végzésére. Azonban nem csupán a vállalatok, a munkaerő képességeinek fejlesztése a követelmény, hanem a helyi társadalmak tágabban értelmezett képességeinek (bizalom, kooperáció, jogkövetés stb.) fejlesztése is fontos a változások előmozdítása érdekében.

G. Fekete Éva, a Miskolci Egyetem Világ- és Regionális Gazdaságtan Intézetének egyetemi tanára az OFTK-ban is megjelenő társadalmi és területi hátrányok értelmezését az aprófalvak szempontjából dolgozta fel. Az aprófalvak teszik ki a magyar településhálózat mintegy harmadát, kedvezőtlen, a gazdasági teljesítményükre negatívan ható demográfiai és társadalmi folyamatokkal terheltek, közlekedési elérhetőségi nehézségekkel küszködnek, nagy a kitettségük a klímaváltozás negatív hatásaival szemben. Ezen általános jellegzetességek természetesen nem minden kistelepülésen jelentkeznek, vannak kimondottan jó helyzetben levő gazdálkodó, turisztikai szolgáltató falvak is, azonban a településkategória mintegy 79\%-ában jelentkezik valamilyen hátrány. Ezek egy részéből 
előny kovácsolható, ha a mikrotényezők fejlesztése helyett strukturális változásokat hajtanak végre. Ehhez az kell, hogy a területi hátrányok kezelését (ami politikai szinten eldöntendő kérdés) a tünetek helyett az okok felszámolásával, integrált, térségi szinten koordinált, falutípusonként differenciált intézkedésekkel hajtsák végre.

Ongjerth Richárd, a Magyar Urbanisztikai Tudásközpont Nonprofit Kft. ügyvezető igazgatója a városfejlesztés, a megyei jogú városok fontosabb dilemmáit vette számba. A városfejlesztésben hiányosságok tapasztalhatók az együttmüködésben, jellemző a rövid távú szemlélet és a szakmai kompetenciák hiánya. Bár a rendelkezésre álló források elköltése már ésszerübb, még mindig jelentős a kihasználatlan kapacitásokat létrehozó, felesleges célok érdekében elköltött pénz. A megyei önkormányzatok a differenciált, kiegyensúlyozott területfejlesztés bázisai, amelyhez egyedi, testre szabott, gazdálkodásorientált tervek, széles körű partnerségi hálózat, felkészült szakembergárda szükségesek. Ehhez a sokszínúséghez a terv- és pályázati rendszereknek is alkalmazkodniuk kell, nem megfelelő az uniformizált tervezés az elkülönülő adottságú térségekben.

Pálvölgyi Tamás, a Budapesti Műszaki és Gazdaságtudományi Egyetem Környezet-gazdaságtan Tanszékének egyetemi docense a területi tervezést a környezeti fenntarthatóság oldaláról vizsgálta. A területi tervezés nem hagyhatja figyelmen kívül a területi egységek környezeti állapotának vizsgálatát, amelyhez a környezettudomány megfelelő indikátorrendszereket dolgozott ki. Az objektív információk mellett a tervezést szolgálja a stratégiai környezeti vizsgálat, amely tervezési segédletként magába foglalja a tervek, koncepciók, programok környezeti hatásának azonosítását, az együttműködést és a kommunikációt. A fenntarthatósági vizsgálatok eredményei alapján a hazai tervezési dokumentumok környezeti elemekkel való kiegészítése ajánlott.

A plenáris ülés zárásaként Major Klára, a Hétfa Kutatóintézet Kft. tudományos főmunkatársa területi tervezési programok végrehajtásának hatáselemzési lehetőségeit, módszertanát ismertette. Ezek az elemzések feltárják valamely beavatkozás vagy a szabályozás változásának egy meghatározott körre (szereplőkre, viselkedésre, változóra) gyakorolt hatását. A hatás kiszüréséhez a változtatás nélküli és változás utáni helyzetek összehasonlítása szükséges, melynek módszertani apparátusát a statisztikai és térökonometriai elemzések adják. A hatáselemzés folyamatosan fejlődő, dinamikus terület, amely napjainkra már a területfejlesztés tényalapú (evidence-based) értékelését is lehetővé teszi.

A tíz plenáris előadásban és az azokat követő vitában konkrét, problémaorientált kérdések és javaslatok hangzottak el, amelyeket a jelenlévők egyetértéssel fogadtak:

- A területi fejlesztések tervezése és megvalósítása során az integrált szemlélet nem kerülhető meg.

- Az alulról szerveződő és a felülről vezérelt tervezés nem egymást kizáró megoldások, együttes és interaktív alkalmazásuk nagyobb koherenciát eredményez. 
- Az Országos Fejlesztési és Területfejlesztési Koncepció komplex és átfogó tervdokumentum.

- Az OFTK-ban rögzített közép- és hosszú távú célok eredményes teljesítése a hatékony végrehajtáson és a szakpolitikai célok közötti prioritások felállításán múlik.

- A növekedés- és fejlődésorientált politikai döntések nem negligálhatják a szakmai és tudományos eredményeket.

- A szinte kizárólagossá váló európai uniós fejlesztési források hatékony elosztását a hazai és uniós célkitűzések megvalósítását veszélyeztető intézményi anomáliák terhelik.

- A területfejlesztés új intézményrendszerének kialakításában és müködtetésében valódi decentralizációra van szükség. Választott testületeknek kell garantálniuk a fejlesztési döntések demokratikus elszámoltathatóságát.

- Az ország területi folyamatait követő kutatói és tervezői kapacitásokra van szükség, amelyek a fejlesztési célok megvalósítását nyomon követik, hatásait értékelik.

A konferencia előadásai elérhetők az MRTT honlapján: www.mrtt.hu.

\section{Jegyzet}

1 Az OFTK az Országos Fejlesztési Koncepciót és az Országos Területfejlesztési Koncepciót integrálja, rögzíti és összehangolja az ágazati és a területfejlesztési célokat. A koncepció 2030-ig szóló hosszú távú jövőképet, valamint fejlesztéspolitikai célokat és elveket határoz meg. Ezek alapján középtávú prioritásokat fogalmaz meg a 2014-2020-as európai uniós programidőszak nemzeti fejlesztéspolitikája számára. Az Országgyủlés az 1/2014. (I. 3.) országgyuulési határozattal fogadta el a Nemzeti Fejlesztés 2030 - Országos Fejlesztési és Területfejlesztési Koncepciót. 